\title{
A Mechanical Analysis of Femoral Resurfacing Implantation for Osteonecrosis of Femoral Head
}

\author{
$\bigcirc$ 学 梅本雄一郎（金沢大） \\ 正 坂本二郎（金沢大） \\ 加畑多文（金沢大） \\ 坂越大悟（金沢大） \\ 高田秀夫（金沢大） \\ 正 尾田十八（金沢大） \\ 富田勝郎（金沢大）
}

Yuichiro UMEMOTO, Graduate School of Natural Science and Technology, Kanazawa University, Kakumamachi, Kanazawa Jiro SAKAMOTO, Juhachi ODA, Graduate School of Natural Science and Technology, Kanazawa University

Tamon KABATA, Daigo SAK AGOSHI, Hideo TAKATA, Katsuro TOMITA, Graduate School of Medical Science, Kanazawa University

Key Words : Bioengineering, Biomechanics, Image-Based Finite-Element Method, Bone, Artificial Femoral Head, Osteonecrosis

\section{1.はじめに}

近年のインプラント材料や設計技術の進歩により, 大腿骨 頭壊死症に対する表面置換型人工骨頭置換術の治療成績 が大きく改善され，注目を集めている(1). 図 1 に, 大腿骨頭壊 死症とそれに適応した表面置換型人工骨頭置換術の外観を 示す. 表面置換型人工骨頭については, 大腿骨頭壊死症だ けでなく若年者の変形性股関節症においても, その後の再置 換に備えて自家骨がより多く残せるという利点が指摘されてい る. しかし, 現在臨床に使われている表面置換型の人工骨頭 は骨頭部に刺入するステムの長さや太さが様々なものが提案 されており，それらの明確な選択基準も示されていない.また， ステム設置角度に対して経験的な推奨值は示されているが, 根拠となる実験や解析も十分には行われていない. 著者らは, 臨床で得られたCT画像に基づき, 表面置換型人工骨頭を 大腿骨頭に設置した有限要素モデルを作成し, 骨の非均質 性を考慮した力学解析から各所の応力状態を評価した ${ }^{(2)}$.こ の研究では, 表面置換型人工骨頭置換術において, 医師の 経験により推奨されている設置方法と設置角度に関して検証 を試み, 両者の妥当性を確認した. 本研究では, より実際の 手術に忠実な条件を再現するため, 骨頭部に壊死領域を仮 定し, その切除部を骨セメントで置換した解析モデルを作成し た. 荷重についても, より臨床に即した条件として, 歩行時の 股関節に作用する分布荷重を与えて解析を行った。この結 果について以下に報告する.

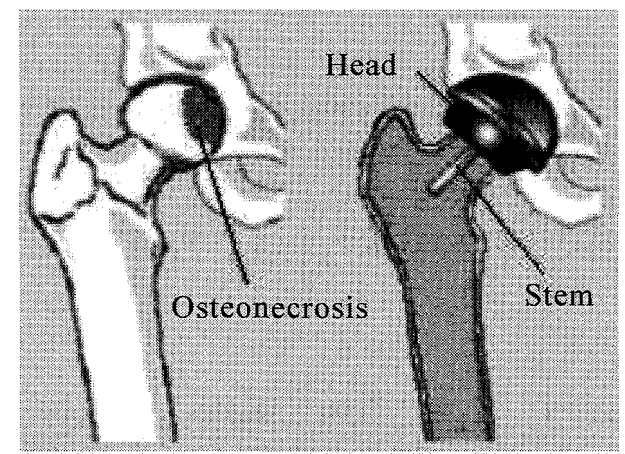

Fig. 1 Schema of femoral resurfacing implantation

\section{2. 解析モデル}

有限要素解析で使用する表面置換型人工骨頭として, Wright Medical Japan 製の CONSERVE 人工骨頭を用いた. 人工骨頭サイズの決定においては, 手術時に大腿骨頸部の 最も細い部分を切り込まないことを前提に, ヘッド部の外径が 大腿骨頭に近いといら条件で市販されているサイズから選択 した.この表面置換型人工骨頭を, 図 2(a)に示す.ここで, L は全長, 1はステム長さ, Rはへッドの外径, r $\mathrm{r}$ はへッドの内径を 表す. 今回選択した人工骨頭のサイズは, $\mathrm{L}=66.5,1=59$,

$\mathrm{R}=42, \mathrm{r}=35.5(\mathrm{~mm})$ である. 人工骨頭の固定には骨セメントを用 い, 手術時と同様にその厚みを $1(\mathrm{~mm})$ として大腿骨, 人工骨頭, 骨セメントを組み合わせた一体型の CAD モデルを作成した. その断面図を, 図 2 (b) に示す. 人工骨頭の設置位置は, 骨 軸から骨頭頂点までの距離が変わらないことを前提に, 大腿 骨の中心を通る骨軸との角度によって決定した. 本研究では, 医師による経験的な推奨值である $140^{\circ}$ を標準的な設置角 度とし, 比較のため, 設置角度が $125^{\circ}$ から $145^{\circ}$ まで $5^{\circ}$ 間 隔の 5 つのモデルを作成した. 比較のため, 人工骨頭を設置 しない正常大腿骨モデルも作成した.これらの CAD モデルに， 要素タイプを四節点四面体, 代表要素長を $3(\mathrm{~mm})$ とした要素 分割を施し, 有限要素モデルを作成した. CAD の操作には Solid Edge (EDS PLM Solutions)を, 要素分割には MSC.Patran（日本 MSCソフトウェア）を用いた.

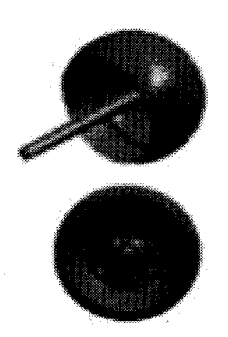

(a)Femoral resurfacing implant

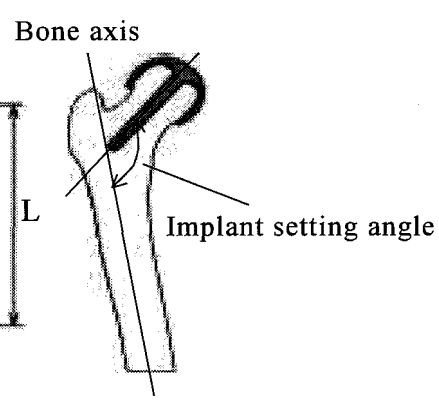

(b)Frontal cross section implant using the analysis Osteonecrosis part

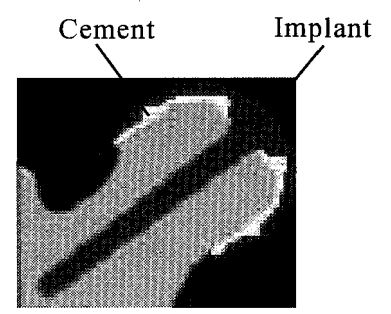

(a) No necrosis model

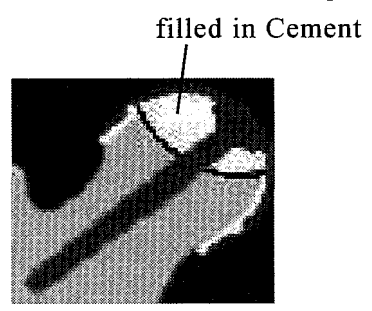

(b) Necrosis model
Fig. 3 Femoral resurfacing implantation models

大腿骨頭壊死症に対する人工骨頭置換術では，骨壊死 部を切除した後, 人工骨頭を挿入して骨セメントで固定する. このため，骨壊死部領域は，骨セメントで充填されることになる. 過去の研究では, 図 3 (a)に示すように骨壊死部を考慮して おらず, 実際の手術に忠実な解析とは言えない. 本研究では, より臨床に近い条件とするため, 図 3 (b)に示すように切除し た骨壊死部が骨セメントにより充填された状況を仮定して解 析を行った. 具体的には, 大腿骨に人工骨頭を挿入したモデ ルに対して以下に示す壊死領域を仮定し, その内部に位置 する有限要素に骨セメントの材料特性を与えて解析する. 大 
腿骨頭壊死症の骨壊死の位置, 重篤度(範囲, 深さ) は, 患 者により様々であると報告されているが，本研究では，その中 でも最も一般的な骨壊死を想定し，壊死領域を定義した。 そ の方法を以下に示す.まず，図 4 に示すように，骨頭中心に 座標原点を置き, 垂直に $45.6^{\circ}$ 水平に $55.7^{\circ}$ 傾けた軸を骨 壞死の基準軸と定めた ${ }^{(3)}$. 臨床では，この軸に対する骨壊死 の深さによって重篤度を決定している: 図 5 に示す 4 つの壊 死タイプは，骨壊死の軸に沿って，球と仮定した骨頭直径の 何割まで骨壊死に侵されているかにより区分されている(4). 本 研究の解析では, 症例数が多く骨頭直径の $5 / 8$ まで壊死に 侵されている Type C を仮定した. また, 骨壊死部の形状は, 骨頭と同等の直径を有する球の一部とみなした。

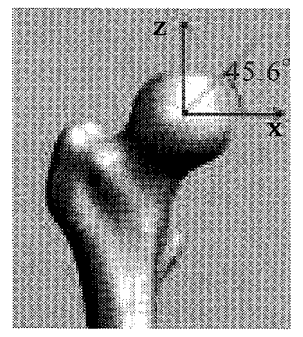

(a)Front-view

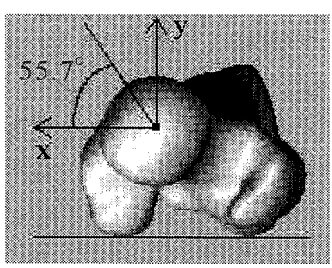

(b) Top-view
Fig.4 Position of osteonecrosis axis in femoral head

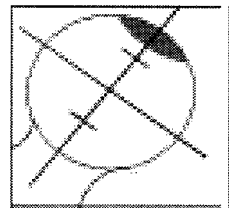

(a) Type A

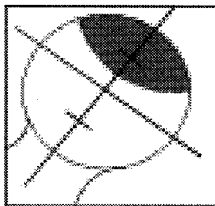

(b) Type $B$ $(0 \sim 1 / 4)$ $(1 / 4 \sim 1 / 2)$

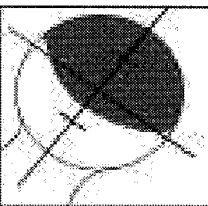

(c) Type $\mathrm{C}$ $(1 / 2 \sim 3 / 4)$

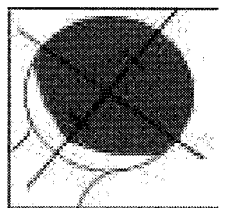

(d) Type D $(3 / 4 \sim 1)$
Fig. 5 Osteonecrosis region with various severities

\section{3. 解析条件}

大腿骨の機械的特性については, CAD モデル作成時に 用いる CT 画像の CT 值から各有限要素の重心点における骨 の質量密度を求め, Carter らが提案した実験式 ${ }^{(5)}$ をいて質 量密度からヤング率Eを計算した.ただし, ポアソン比はv $=0.4$ で一定とした. 人工骨頭の材料である Co-Cr 合金につい ては, $\mathrm{E}=200(\mathrm{GPa}), v=0.3$ とし, 骨セメント(PMMA)について は, $\mathrm{E}=2(\mathrm{GPa}), \nu=0.19$ とした. 汎用の有限要素ソフトウェアで は, 要素個々に異なる材料定数を割り当てることが困難であ る. そこで, 有限要素解析には大規模計算力学システムの ADVENTURE (ADVENTURE プロジェクト) (6)を用い, CT 值 からの各要素のヤング率の導出には専用の前処理ソフトウェ アを作成して計算を行った. 境界条 件としては, 歩行時の股関節に作用 する分布荷重を想定し, 図 6 の斜線 に示すような荷重を与えた。ここで, $\mathrm{R}, \mathrm{P}$ は分布荷重の合力, $\theta_{\mathrm{R}}, \theta_{\mathrm{p}}$ は $\mathrm{Z}$ 軸と $\mathrm{R}, \mathrm{P}$ のなす角, $\theta_{\mathrm{CE}}$ は $\mathrm{CE}$ 角 を表す。本研究では $\mathrm{R}=1500(\mathrm{~N})$, $\mathrm{P}=1000(\mathrm{~N}), \theta_{\mathrm{R}}=13^{\circ}, \theta_{\mathrm{P}}=20^{\circ}$, $\theta_{\mathrm{CE}}=35^{\circ}$ とした ${ }^{(7)}$. モデル最遠位 端面の全節点を完全拘束し, 有限

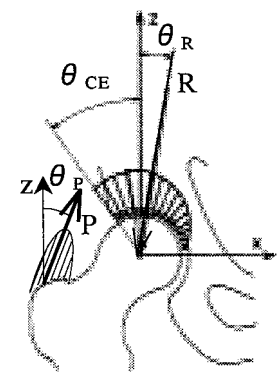
要素解析を行った

Fig. 6 Loading condition

\section{4.解析結果と考察}

各モデルの骨頭部断面における応力分布図を，図 7 に示 す. 骨頭上部の負荷領域からステムを通り，大腿骨頸部下方 の皮質骨へとつながる高応力域は, 設置角度の増加と共に 変化している. また, この高応力域は, 設置角度 $135^{\circ}$ から $145^{\circ}$ で, 正常大腿骨の荷重伝達経路に類似していることが 分かる. 次に, 設置角度 $125^{\circ}$ の骨セメントと人工骨頭の応力 分布を, 図 8 に示す. 両モデルとも骨頭エッジ部に, また人工 骨頭はステム部に比較的高い応力が発生することが分かり, 図 7 で示した荷重伝達経路を確認できる. 次に, 骨セメントに おける最大主応力の最大值を, 図 9 に示す. 設置角度 $130^{\circ}$ $140^{\circ}$ では低い応力値を示すが, $135^{\circ}$ では高い応力が発生 しており,これは骨頭内部の荷重伝達経路の相違に起因する と考えられる.

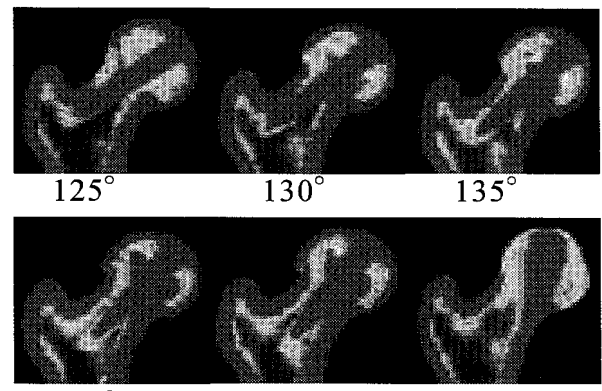

$140^{\circ}$

$145^{\circ}$

Intact

(MPa) 25

Fig. 7 Mises stress contour of frontal cross section

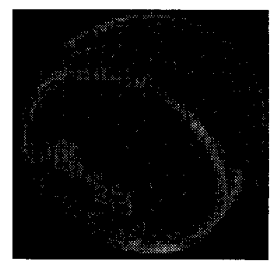

(a) $125^{\circ}$ Cement
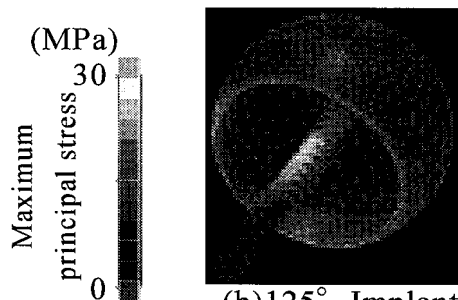

(b) $125^{\circ}$ Implant
$(\mathrm{MPa})$

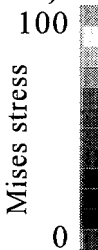

Fig. 8 Stress contour of implant and cement

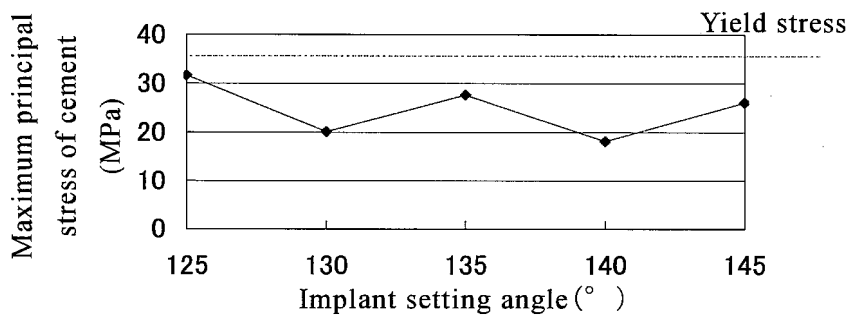

Fig.9 Maximum principal stress of cement

\section{5.おわりに}

本研究では, より実際の手術に忠実な条件下で,人工骨 頭の力学解析を行った. 骨セメントの応力は, $140^{\circ}$ で最小值 をとることから，今回の評価においては，人工骨頭置換術に おいて推奨されている設置角度は，ほぼ妥当であると考えら れる。

\section{参考文献}

(1) Wyness L, et al., BMC Health Services Research, http://www.biomedcentral.com/1472-6963/4/39, 2004

(2) 梅本雄一郎 坂本二郎 他 5 名, 第 16 回バイオフロンテ イア講演会講演論文集, No.05-53, 101-102, 2005

(3) Takahashi Nishii, et al., Journal of Orthopaedic Research, 20, 130-136, 2002

(4) Koh Shimizu, et al., The Journal of Bone and Joint Surgery, 76A-2, 215-223, 1994

(5) Carter DR, Hayes WC, J. Bone Joint Surg., 59A, 954-962,1977

(6) http://adventure.q.t.u-tokyo.ac.jp/jp/

(7) M.Ipavec, et al., Journal of Biomechanics, 32, 1229-1235, 1999 